\title{
TECHNIQUE OF USING SEDIMENTOGRAPH MASTERSIZER 2000 FOR GRANULOMETRIC ANALYSIS AND RESULTS INTERPRETATION QUESTION
}

\author{
S.M. Stadnichenko, V.O. Podoba
}

\section{МЕТОДИКА ВИКОРИСТАННЯ СЕДИМЕНТОГРАФА MASTERSIZER 2000 ДЛЯ ГРАНУЛОМЕТРИЧНОГО АНАЛІЗУ Й ПИТАННЯ ІНТЕРПРЕТАЦІї ОТРИМАНИХ РЕЗУЛЬТАТІВ}

\author{
С.М. Стадніченко, В.О. Подоба
}

The considered classical methods of the analysis granulometry structure, and also modern technologies and devices. The described features of use sedimentograph Mastersizer 2000 at research granulometry structure of breeds. The made conclusions on the basis of the received results. The specified recommendations concerning reception of more exact and reliable results at carrying out engineering - geological and lithologic researches.

Key words: granulometry structure, a technique, accuracy of results, laser diffraction.

Розглянуто класичні методи аналізу гранулометричного складу, а також сучасних технологій і приладів. Описано особливості використання седиментографа Mastersizer 2000 при дослідженні гранулометричного складу порід. Зроблено висновки на основі отриманих результатів. Зазначено рекомендації щодо одержання більше точних і надійних результатів при проведенні інженерно-геологічних і літологічних досліджень.

Ключові слова: гранулометричний склад, методика, точність результатів, лазерна дифракція.

\section{ВСТУП}

Визначення властивостей осадових порід $€$ важливим питанням при різноманітних літологічних дослідженнях та інженерно-геологічних вишукуваннях. Сучасні досягнення в цій сфері науки вимагають удосконалення вже існуючих та розробки нових методик для застосування нових технічних засобів.

Показники, що характеризують гранулометричний склад ґрунтів, дають уявлення про їх природу, фізико-механічні властивості й дозволяють приблизно оцінити можливі зміни цих властивостей і стану ґрунтів при будівництві споруд чи здійсненні інженерних заходів. Гранулометричний склад $є$ одним із таких показників. Визначення цього параметра дозволяє класифікувати породу й використати відповідну методику подальших досліджень [5].

Вивчення гранулометричного складу порід дає можливість аналізувати умови осадконакопичення і визначати генезис досліджуваних порід [7].

Гранулометричний склад характеризує породу відповідно до розміру складаючих їі частинок. Він виражає процентний вміст фракцій різного розміру по відношенню до маси абсолютно сухого ґрунту [5].

Mastersizer 2000 (виробник Malvern, Велика Британія) - сучасний високотехнологічний аналізатор розміру частинок, принцип роботи якого базується на лазерній дифракції світла. Седиментограф дозволяє вимірювати часточки розміром від 0,1 до 2000 мкм.

У даній статті наведено методику та результати проведення гранулометричного аналізу дисперсних порід за допомогою лазерного седиментографа Mastersizer 2000, розглянуто певні аспекти використання приладу та подано інтерпретацію отриманих результатів.

\section{КЛАСИЧНІ ТА СУЧАСНІ МЕТОДИ ГРАНУЛОМЕТРИЧНОГО АНАЛІЗУ}

Під гранулометричним аналізом у літології розуміють засоби, що дозволяють визначати вміст частинок різного розміру в різних породах [8].

Найбільш простим є гранулометричний аналіз пісків та слабозцементованих пісковиків, які розпадаються на складові зерна при невеликому тиску. Однак в останньому випадку серед дрібних піщаних та крупних алевритових фракцій часто зустрічаються агрегати більш дрібних зерен. У таких випадках вони можуть бути усунуті за допомогою додавання диспергуючої речовини або кип'ятінням наважки у воді чи слабкій соляній кислоті [8].

Основним методом вивчення зернистості пісків $є$ ситовий аналіз. У ґрунтознавстві для гранулометричного аналізу використовуються сита з комірками 2,0; 1,0; 0,5; 0,25 та 0,1 мм. Для більшої ефективності й сталого режиму просіювання набір сит розміщується в спеціальний прилад - ротап [8]. 
Гранулометричний аналіз глинистих порід дає менш надійні результати порівняно з аналізом піщаних відкладів. Причина цього полягає в утворенні глинистими частинками агрегатів, які виникають під час ї осадження. Тому результати аналізу глинистих порід значною мірою залежать від способу підготовки зразків до аналізу.

Класичні гідравлічні методи гранулометричного аналізу глин засновані на залежності між розміром зерен та швидкістю їх осадження у воді. Найбільш поширені в практиці геологічних лабораторій методи, описані нижче.

В основі розрахунків, які виконуються при гідравлічних способах аналізу, лежить формула Стокса. Швидкість осадження частинок сферичної форми залежить від радіуса частинок; питомої ваги частинок; питомої ваги води; прискорення сили тяжіння та величини в'язкості води. Дана формула застосовується до частинок розміром від кількох десятих міліметра до 0,005 мм. Із усіх частинок з однаковою масою, найбільшою швидкістю осадження характеризуються сферичні частинки. Повільніше за все (іноді на 30-40\%) осаджуються пластинчасті частинки. На швидкості осадження позначається також питома вага зерен [8].

Метод Сабаніна використовується головним чином для аналізу дрібно- і тонкозернистих пісків. Він дає можливість виділити такі фракції: >0,1; 0,1-0,05; 0,05-0,01 i <0,01 мм. При вмісті частинок $<0,01$ мм понад 10-15\% слід звертатися до інших методів. Дані Сабаніна є менш точними порівняно з даними, отриманими за формулою Стокса, тому що перші не враховували форму, мінеральний склад часток, а також зміни в'язкості води при різних температурах. Суттєвим недоліком даного методу є значна тривалість проведення досліду [5, 8].

Ваговий седиментометр ВР-4 використовується в Сибірському фізико-технічному інституті Томського держуніверситету, в НДІ прикладної математики і механіки Томського держуніверситету. Прилад працює на основі методу пошарової седиментації частинок. Особливість методу полягає у врахуванні неправильної форми частинок. Розмір частинок визначається за швидкістю їх осадження з використанням закону Стокса [1].

Метод Осборна характеризується відсутністю яких-небудь стандартних строків відстоювання суспензії. Відділення одних зерен від інших контролюється винятково під мікроскопом, і зливання відбувається тоді, коли в полі зору не залишається частинок заданого розміру. Глибина зливання визначається приблизно за формулою Стокса [8].

Метод АзНдІ. У багатьох лабораторіях великого поширення набув метод відмулювання, розроблений у Баку П.П. Авдусіним і В.П. Батуріним [8].

Метод Робінсона (піпеточний метод) використовується переважно для гранулометричного аналізу глинистих порід, що містять значну кількість частинок <0,01 мм, хоча він передбачає визначення й більших частинок.

Основою піпеточного методу, на відміну від методів Сабаніна й Осборна, є не зливання стовпа суспензії, а відбір з неї піпеткою проби, в якій і визначається вміст частинок певного розміру. Враховуючи неможливість відбору окремих фракцій для наступного мінералогічного аналізу, не можна рекомендувати цей метод для широкого застосування в петрографічній практиці. Однак для визначення вмісту в породі особливо тонких частинок, які в сумі складають фракцію < 0,01 мм, метод піпетки, незважаючи на його недоліки, дає результати найбільш правильні та залишається більш зручним через швидкість й легкість його здійснення [5,8].

Гранулометричний аналіз погано відсортованих піщано-глинистих порід проводитися комбінованим способом. Для піщано-алевритових відкладів слід застосовувати ситовий аналіз, а для глинистих - один з гідравлічних методів. Комбінований аналіз характеризується комбінацією цих методів, причому для поділу крупних і дрібних частинок використовується відмучування [5].

У даний час високого рівня розвитку набув ситовий аналіз - розроблені автоматизовані прилади і пристрої з вбудованим мікропроцесором і можливістю підключення до комп'ютера, наприклад Analysette німецької компанії Fritsch. Дане обладнання дає можливість проводити вимірювання в широких діапазонах: 20 мкм - 63 мм, 5 мкм - 100 мкм, 63 мкм - 63 мм.

Лазерні аналізатори розміру частинок «Анализетте 22» моделі NanoTec та MikroTec (FRITSCH, Німеччина) є універсальними приладами для виміру розмірів частинок у суспензіях, емульсіях, порошках й аерозолях, діапазон вимірювань - 0,3-300, 0, 1-6000, 0,1-1250 мкм. Аналізатори призначені для визначення розподілу частинок за розмірами за допомогою лазерної дифракції, використовують 
фізичний принцип розсіювання електромагнітних хвиль. Частинки в паралельному лазерному промені розсіюють світло на постійний кут, величина якого залежить від діаметра частинок. За допомогою комплексної математичної обробки розподілу інтенсивності розсіяного світла можна розрахувати розподіл частинок за розмірами серед частинок, що розсіюються. У результаті одержують діаметр частки лазерної дифракції, діаметр якої еквівалентний кулі з однаковим розподілом розсіяного світла.

Нова і технологічно завершена модель седиментографа LA-950 (виробник HORIBA) дозволяє вимірювати розміри частинок, що перебувають у діапазоні від 0,01 до 3000 мкм менш ніж за 20 с. Визначення розміру частинок засновано на теорії розсіювання Мія. Потужне програмне забезпечення в комбінації із високотехнологічною оптичною системою і рядом пристроїв для взяття проб дозволяє адаптувати систему для будь-яких застосувань.

CAMSIZER є приладом для визначення розмірів частинок, заснованим на принципі цифрового аналізу зображення. Прилад призначений для високоточного виміру розмірів частинок у діапазоні від 36 мкм до 16 мм без перемикання між різними діапазонами виміру. Він не тільки виконує високоточні аналізи по визначенню розмірів частинок, але й одночасно подає інформацію про форму частинок. Результати можуть бути представлені в тому ж вигляді, що й результати розсіювання й седиментаційного аналізу.

Система Lasentec дозволяє здійснювати безперервний моніторинг розміру зважених (у рідині або псевдорозрідженому шарі) частинок у діапазоні 0,5 мкм - 2 мм із точністю 0,25 мкм, отримуючи розподіл частинок за розмірами кожні 2 с. Відмінною від інших, позитивною рисою системи $€$ відсутність вимог до форми частинок - вони можуть бути будь-якої форми, необов'язково сферичної.

Також використовується ряд обладнання для гранулометричного аналізу і поділу на фракції за розмірами Частинок: апарати для розсіювання типу «Ротап»; установка седиментаційного розподілу «Адап»; центробіжні апарати для виділення тонких частинок.

Один із приладів, що застосовується для поділу порід на фракції за розміром частинок, є спіральна колонка, що обертається завдяки планетарній центрифузі. Зразок розподіляється на фракції під дією центробіжних сил завдяки різній швидкості руху частинок різного розміру вздовж стінок колони.

Використання нових методик и приладів при аналізі гранулометричного складу осадових гірських порід дозволяє отримати бажані результати без розділення піщаної та глинистої складових, значно зменшуючи затрати зусиль і часу. Проте існують певні проблеми і недоліки використання даного обладнання.

\section{ПРИНЦИП РОБОТИ ЛАЗЕРНОГО СЕДИМЕНТОГРАФА}

Робота приладу базується на явищі дифракції (заломлення й поглинання) лазерного променя частиночками досліджуваних зразків.

Седиментограф Mastersizer 2000 працює використовуючи оптичний елемент щоб виміряти дійсне розсіяння променів на зразку. Джерелом світла $є$ два твердотільних рубінових лазери, один працює в червоному спектрі, а другий - у синьому. Це потрібно для збільшення роздільної здатності приладу. Потрапляючи на зразок, лазер частково поглинається, а частково розсіюється. Розсіяне проміння фіксується рядом детекторів і обробляється програмним забезпеченням. Існує багато моделей та теорій, за якими аналізатор може виміряти розмір частинки [2].

Одна з найпростіших теорій - це модель Франгофера. Модель ілюструє один із типів дифракції дифракцію Фраунгофера. Параллельный пучок світла потрапляє на перешкоду. За принципом Гюйгенса кожна точка хвильового фронту стає джерелом вторинного випромінювання. Тому лазерний промінь здатен огинати перешкоди, розміри яких рівні довжині його хвилі. Ця модель може передбачити розсіяння променя, коли той потрапляє на непрозорий сферичний диск відомого радіуса [2, 3, 9].

Широко застосовується також теорія Мія. Вона чітко передбачає поведінку розсіяного світла від всіх матеріалів, а також за будь-яких розмірів. Теорія Мія була розвинена, щоб передбачити шлях за яким світло розсіюється сферичними частинками. Ця теорія більш точна ніж теорія Франгофера. Завдяки відомому діапазону розмірів часточок та інших деталях про їх структуру є можливість точно передбачити шлях, яким світло буде розсіюватись. Кожен розмір частинки має власні характеристики розсіяння променів $[2,3,9]$.

Зразок готується й розчиняється до точної концентрації, а потім підноситься до оптичного елемента. Підготовка зразка є найважливішою стадією вимірювання. 
Вимірювання розсіяних променів проводиться так. Детектор в оптичному елементі зроблено 3 багатьох індивідуальних детекторів. Кожен детектор збирає розсіяне зразком світло. Ряд детекторів роблять моментальний знімок розсіяного зразка. Потім прилад порівнює цей знімок із знімком, коли промінь проходити без розсіяння. Роблячи лише один знімок, можна одержати уявлення про зразок. Mastersizer 2000 робить за одне вимірювання понад 2000 спалахів, кожен спалах триває 1 м.с.

\section{ВПЛИВ СКЛАДУ, ФОРМИ ЧАСТИНОК ТА ОПТИЧНИХ ВЛАСТИВОСТЕЙ ПОРОДИ НА РЕЗУЛЬТАТИ ГРАНУЛОМЕТРИЧНОГО АНАЛІЗУ}

При використанні седиментографа Mastersizer 2000 для гранулометричного аналізу необхідно задати певні характеристики породи: мінеральний склад, форма частинок, ступінь окатоності зерен, оптичні властивості, діапазон розмірів частинок, що складають досліджуваний зразок, та ін.

Для більшої точності й достовірності результатів аналізу гранулометричного складу мають передувати дослідження мінерального складу та морфометрії зерен зразків. Для визначення необхідних параметрів досліджуваних зразків був використаний скануючий електронний мікроскоп JEOL-6490 LV із енергодисперсійною приставкою INCA Energy-450.

У програмному забезпеченні седиментографа вже закладені значення індексів заломлення та дисперсії більшості літологічних різновидів. Але, враховуючи складність і комплексність літологічного складу гірських порід, у разі необхідності є можливість отримати додаткову інформацію щодо цих параметрів із спеціального довідника «Sample Dispersion \& Refractive Index Guide». Базу даних у програмному забезпеченні можна оновлювати, необхідно лише задати ступінь заломлення й ступінь поглинання речовин, що додаються.

Мінеральний склад відіграє вирішальну роль, оскільки робота приладу базується на принципі лазерної дифракції променя світла. При потраплянні лазерного променя на зразок частина променя розсіюється, а частина поглинається. Важливою характеристикою для досліджень є ступінь поглинання. Під час вимірювання необхідно вказати мінеральний вид зразка, якому відповідають оптичні характеристики: ступінь поглинання, індекси заломлення та дисперсії.

Під час вимірювання застосовуються одна з вказаних вище теорій (Фраунгофера або Мія). Тому для точності вимірювань необхідно вибрати модель, відповідно до форми частинок зразка. Морфологія мінеральних індивідів, що характеризується ступенем ізометричності, виражається в різному співвідношенні їх довжини, ширини і товщини. Ізометричні зерна мають однакові розміри у всіх напрямках - кристали алмазу, магнетиту, гранату, сфалериту й піриту. Ізометричну форму зерен мають кварц, польові шпати, олівін, кальцит та ін. Зерна кварцу можуть мати також сферичну або близьку до неї форму залежно від ступеня окатоності. Мінерали не ізометричної форми мають не однакові розміри в різних напрямках. Прикладом видовжених мінералів $є$ турмалін, берил, скаполіт; галуазит має різко виражену трубчасту форму. Сплощені мінерали представлені таблитчастими, листуватими і дрібно лускуватими різновидами. Зазвичай сплощений вид мають ільменіт, гематит, біотит, хлорит; сплощенно-видовжену форму зерен - воластоніт, сподумен, антимоніт. Зерна серициту мають лускувату та пластинчасту форму, різкі обриси частинок, гострі краї лусочок; слюди, гідрослюди часто представлені тонкими ізометричними лусочками, чи пластинками видовженими пластинками; монтморілонітові глини частіше за все утворюють хмароподібну масу з нечіткими обрисами дрібних частинок; каолініт представлений переважно напівпрозорими й непрозорими кристалами гексагональної форми чи їх уламками $[4,6,8]$. (Рис.1).

Для отримання найбільш достовірних і точних результатів необхідно виконати декілька циклів вимірювань залежно від кількості мінеральних видів у даному зразку. Перед кожним циклом потрібно задавати параметри певного мінерального виду та обирати відповідно до форми частинок модель.

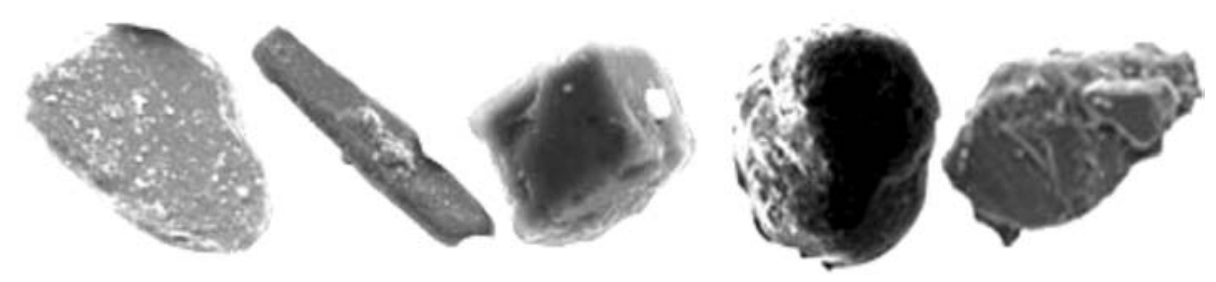

Рис. 1. Ілюстрація форм, яких можуть набувати частинки (зерна) породи 
Шляхом усереднення результатів усіх циклів отримується бажаний результат аналізу гранулометричного складу. Наприклад, при проведенні аналізу гранулометричного складу зр. №1 вимірювання виконувались у такій послідовності: аналіз мінерального складу виявив присутність піщаних частинок (зерен кварцу) та глинистих мінералів (монтморилоніту), виконані вимірювання при заданих параметрах кварцу за моделлю Франгофера та параметрами монтморилоніту за теорією Мія. Після усереднення результатів отримуємо гранулометричний склад зразка.

Також для більшої точності вимірювань потрібно вказати діапазон розмірів частинок, що складають досліджуваний зразок (рис. 2).

Оскільки для повноцінної й максимально достовірної характеристики досліджуваних порід визначення всіх вище вказаних параметрів $€$ необхідним у будь-якому напрямі досліджень, то затрати часу й зусиль не можна віднести до недоліків використання даного приладу.

Для оцінки можливостей седиментографа Mastersizer 2000 були досліджені зразки ( попередньо була виконана традиційними методами оцінка гранулометричного складу даних зразків для порівняння ):

1. Пісок з сучасних озерно-алювіальних відкладів заплави р. Нивка (al PI-III) (Софіївська Борщагівка, гл. 7 м). Даний зразок обраний через добру відсортованість та окатаність зерен. (рис. 2 a, 3).

2. Червона алеврит-аргілітова порода (Мар'янівське 50, 3/1, гл.3834-3838 м, Картомишська світа P1). Зразок містить частинки глинисто-алевритової розмірності із певним відсотком слюдистих частинок, що відображається у гранулометричному складі. (рис. 2 б, 4).

3. Зразок сучасних донних відкладів о-ва. Коса Тузла (Н03 гл. 0,1 м). Генезис утворення даного зразка обумовлює погану відсортованість і різноманітність форми частинок, що знайшло відображення в результатах аналізу гранулометричного складу (рис. 5).

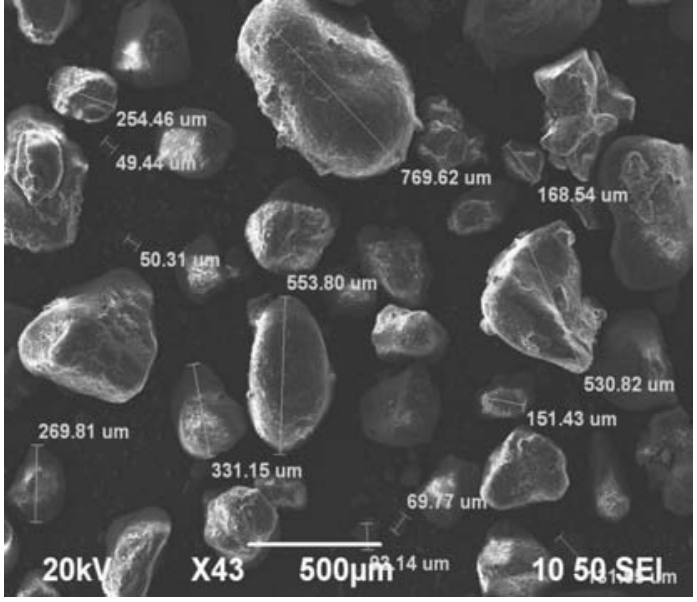

a)

Рис. 2. Приблизна оцінка діапазону розмірів зерен зр. 1 та 2.

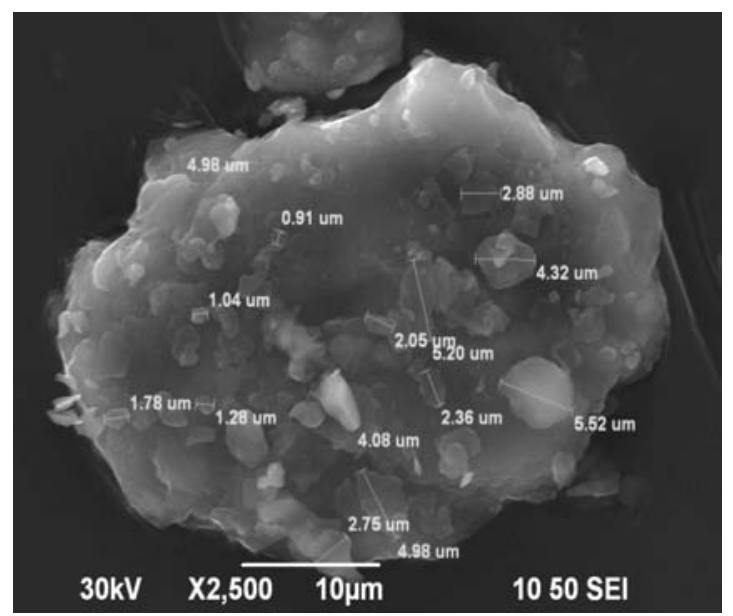

б)

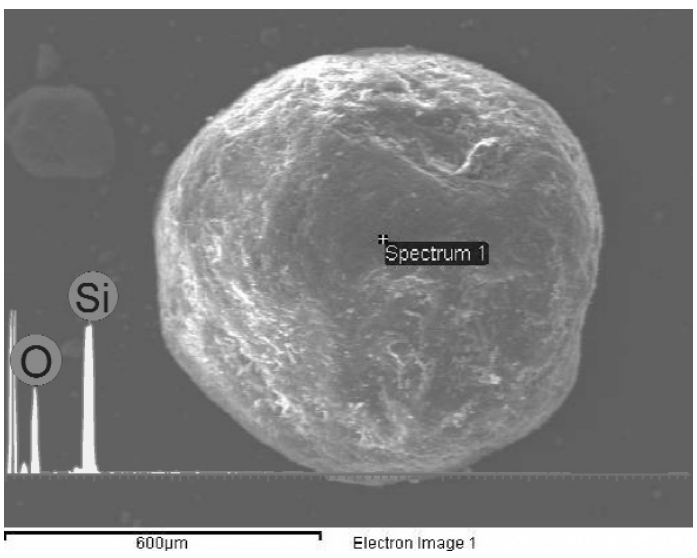

а) зерно кварцу сферичної форми, добре окатане;

Рис. 3. Результати аналізу мінерального складу зр. 1.

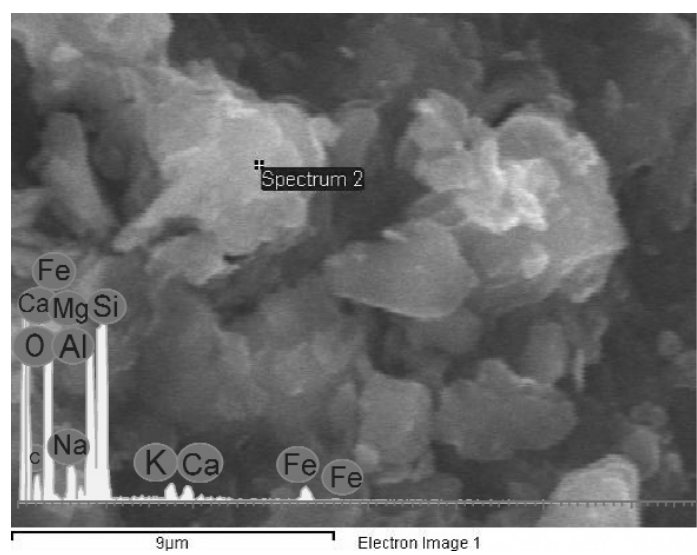

б) монтморилоніт у вигляді скупчення тонких ізометричних лусочок 


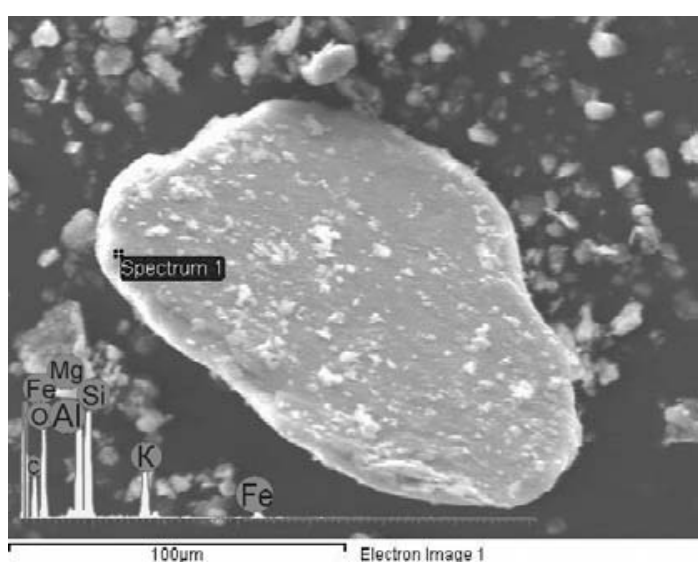

а) глауконіт

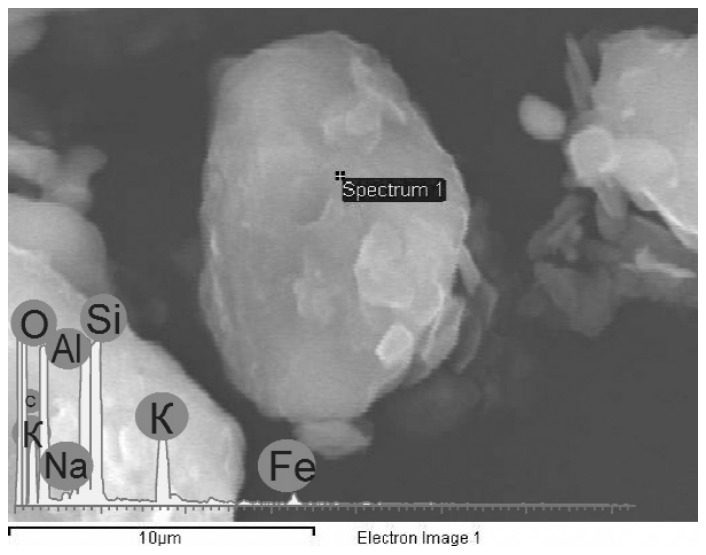

в) іліт

Рис. 4. Результати аналізу мінерального складу зр. 2.

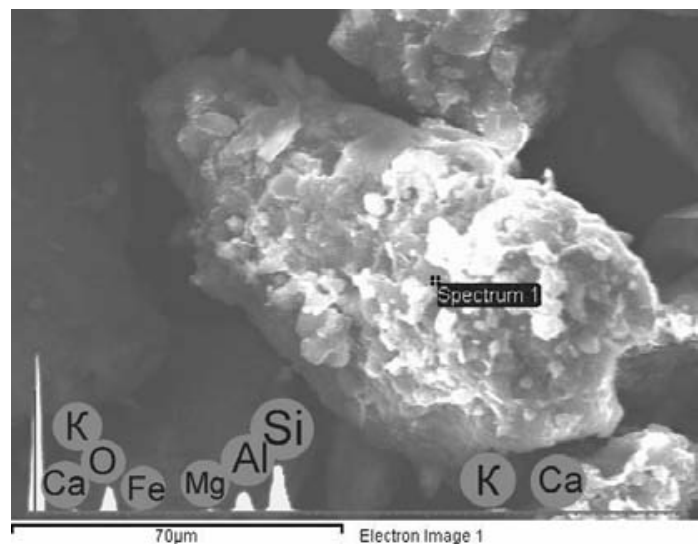

а) каолінізований польовий шпат

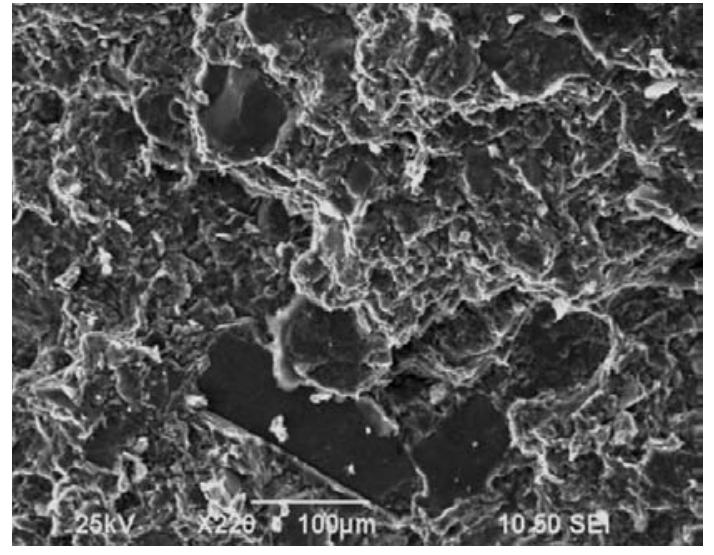

б) слюдисті частинки в глинистій масі

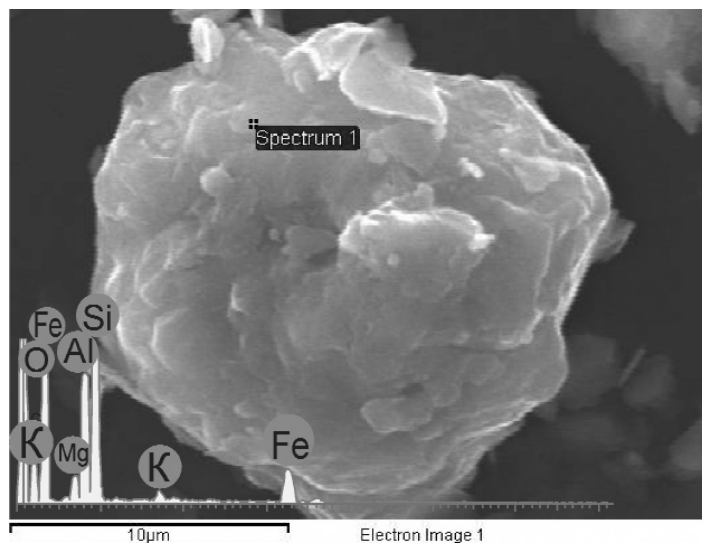

г) монтморилоніт

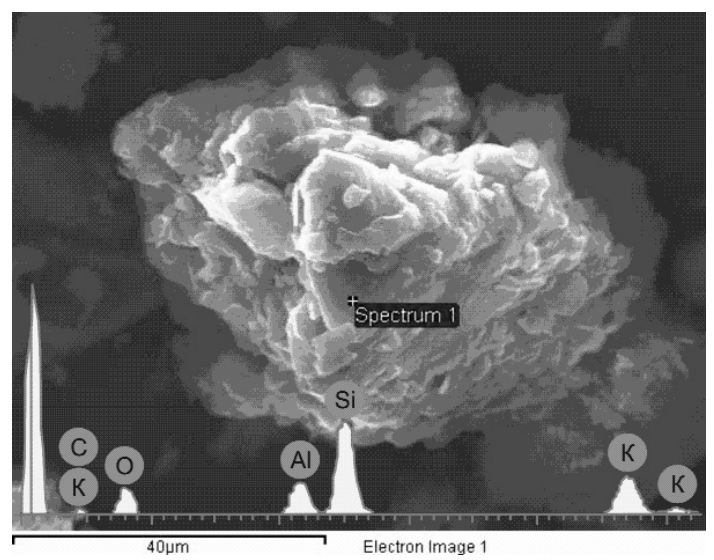

б) каолінізований польовий шпат

Рис. 5. Результати аналізу мінералогічного складу зр. 3.

Результати дослідження мінерального складу та форми зерен зразків за допомогою електронного скануючого мікроскопа наведені нижче.

Розподіл частинок може бути поданий у вигляді графіку відповідно до об'єму, площі поверхні частинок, довжини чи кількості частинок. Важливо враховувати, що вимірювання Mastersizer базується на визначенні саме об'єму частинок, далі йде лише математичне перетворення отриманих даних. Тому розподіл частинок за іншими параметрами може містити певну похибку. Важливо зазначити, що дані, представлені відповідно до об'єму, максимально відповідають реальному розподілу частинок за фракціями, використання інших параметрів доцільно в інших випадках. Нижче на рис. 6 представлено графік порівняння результатів. 


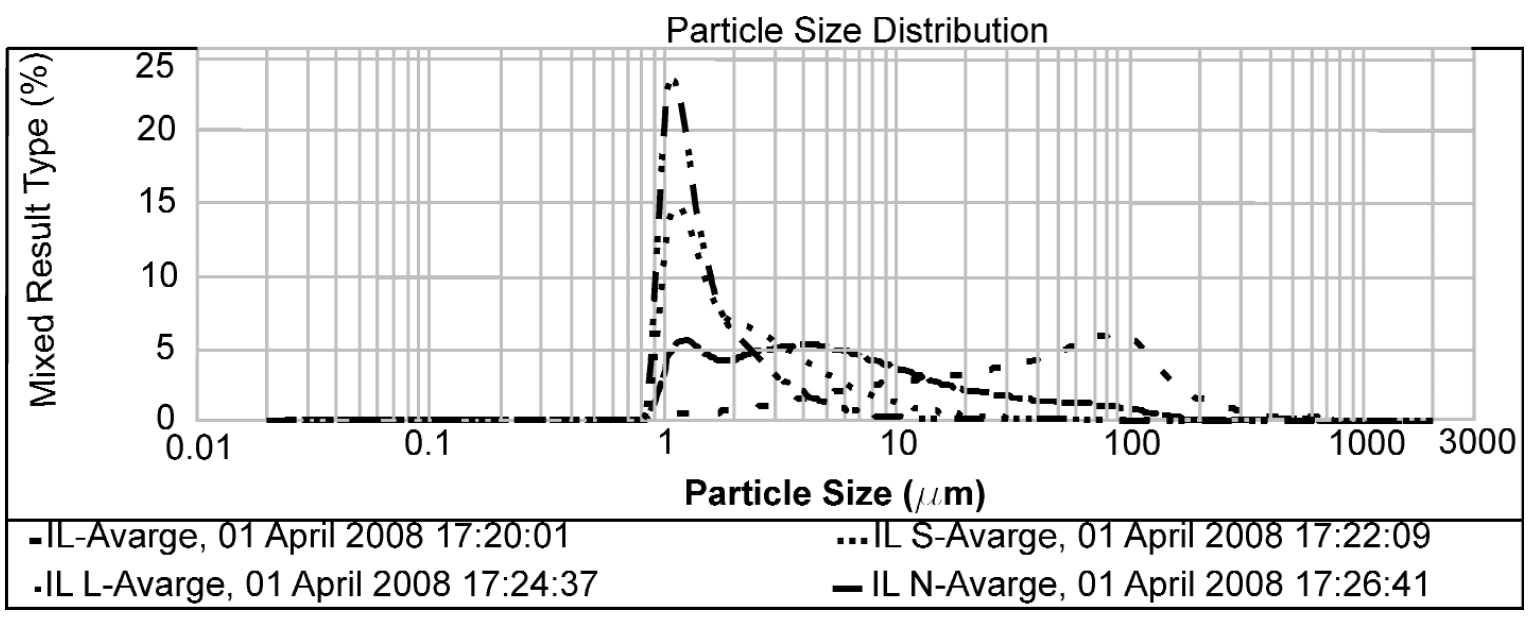

Pис. 6. Графік розподілу частинок по відношенню до об'єму, площі поверхні (S), довжині частинок (L) та їх кількості (N).

Отже, надалі всі результати будуть представлені по відношенню до об'єму частинок порід.

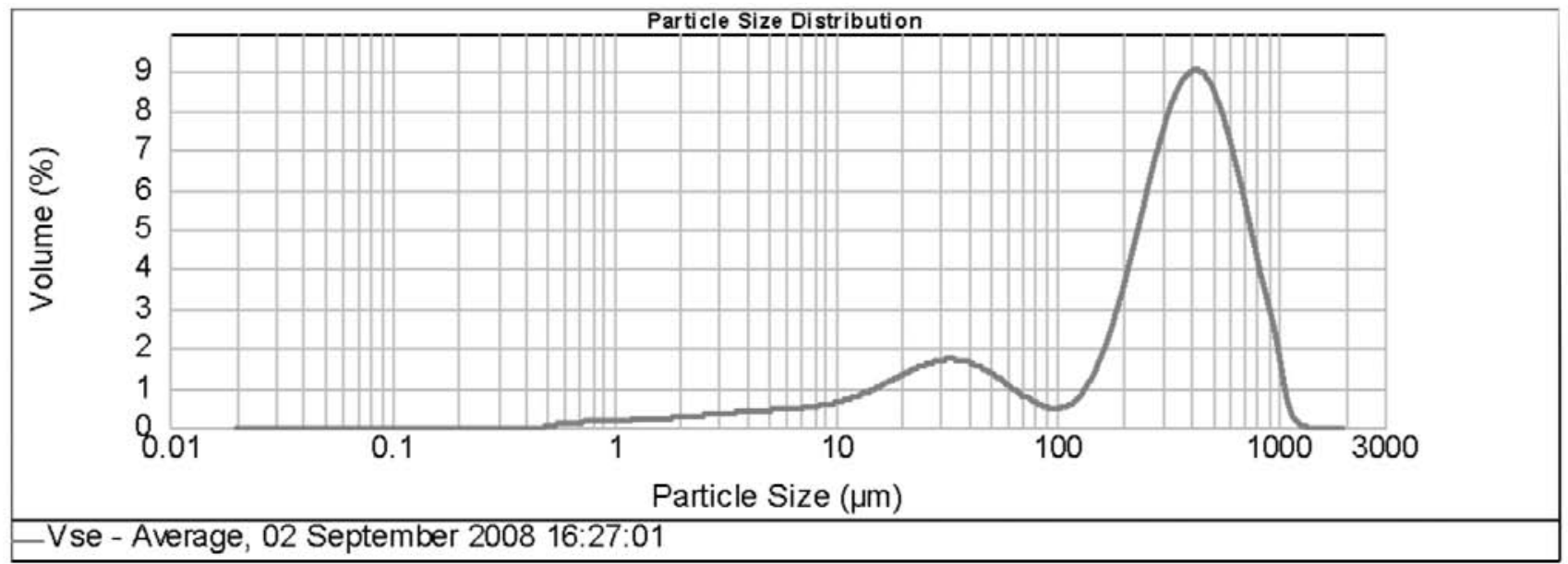

Рис. 7. Результати аналізу гранулометричного складу зр. 1.

Графік (рис. 7) відображає бімодальність розподілу частинок зразка на піщану і алевритову складові. Максимальна кількість частинок даного зразка припадає на діапазон розмірностей (фракцію) 0,25-0,5 мм, відповідно до класифікації пухких осадових порід зразок можна віднести до класу пісок дрібний [5]. Важливо зазначити, що отримані результати збігалися із результатами класичних методів із незначною похибкою в оцінці вмісту частинок $>1$ мм. Похибка обумовлена тим, що при проведенні досліду не всі крупні частинки потрапляють до лінзи через значну масу.

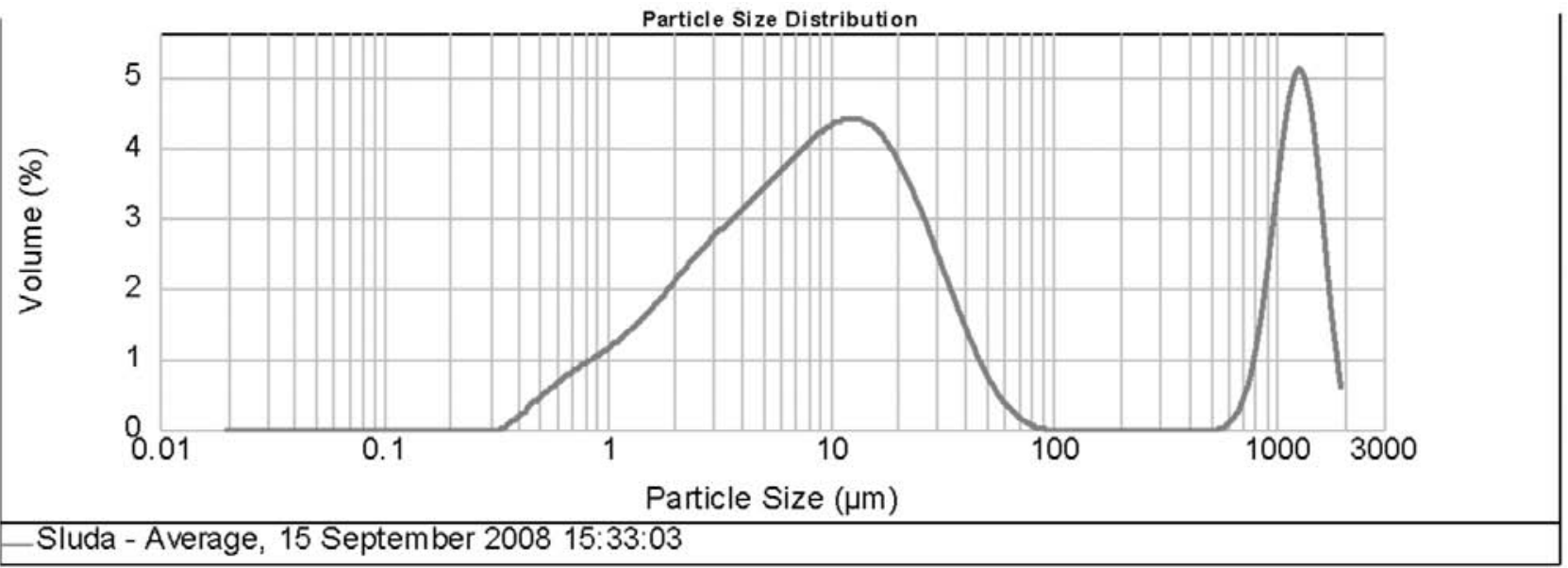

Рис. 8. Результати аналізу гранулометричного складу зр. 2. 
Даний графік аналізу гранулометричного складу чітко відображає наявність двох мінералогічних різновидів, які складають даний зразок: частки іліту представлені зернами розмірністю 1-100 мкм, слюдисті частинки представлені зернами розмірності 0,7-1 мм. За отриманими результатами породу можна віднести до змішаного типу пеліто-алевритових осадів [7].

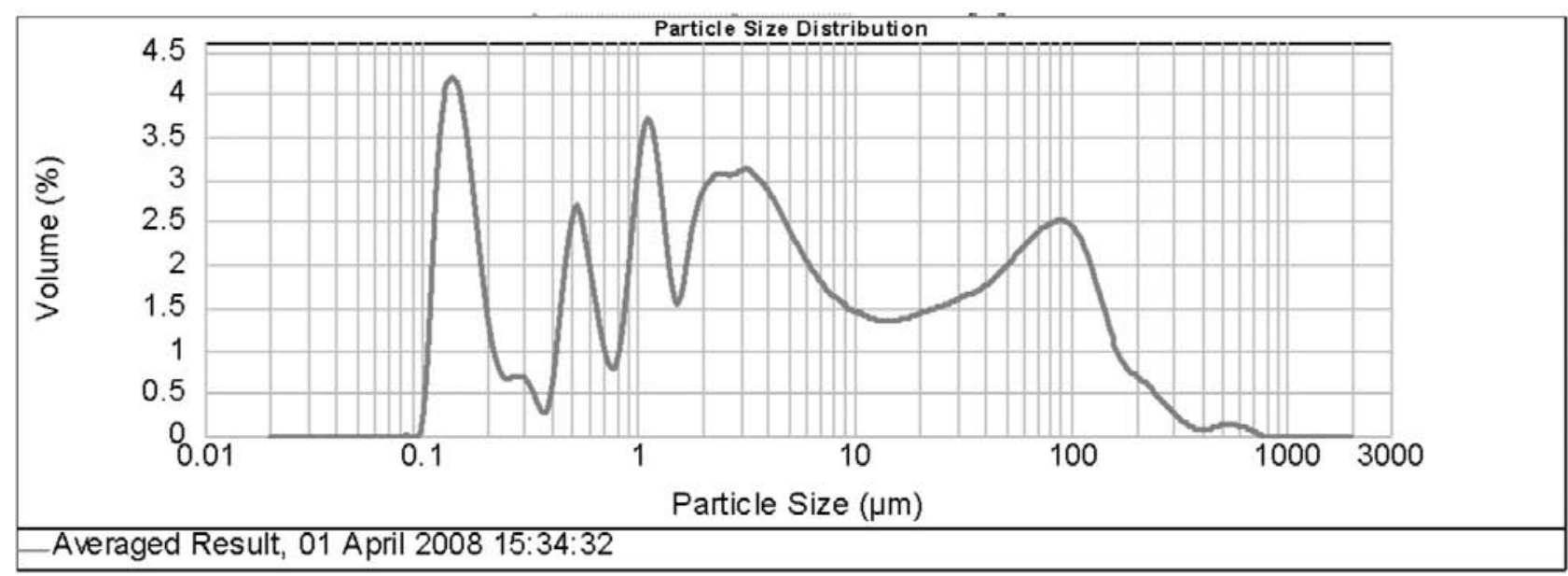

Рис. 9. Результати аналізу гранулометричного складу зр. 3.

Отриманий полімодальний графік (рис. 9) відображає складність умов осадконакопичення в даному регіоні- о-в Коса Тузла. Для класифікації даного зразка була використана гранулометична класифікація донних відкладів Л.В. Пустовалова. Відповідно до отриманих результатів досліджень породу можна віднести до пелітового типу осадів - мул піщанистий [7].

Використання даного приладу дає можливість отримати розподіл частинок у зразку за розміром із великою точністю, але при цьому не виконується розділення на фракції. В програмному забезпеченні закладена функція експорту результатів вимірювання у вигляді графіків і таблиць, за допомогою програмного засобу Excel можливо вирахувати вміст частинок певного розміру за виділеними фракціями.

Існує ряд факторів, що можуть призвести до виникнення похибки вимірювання: перевищення необхідної концентрації частинок зразка в досліджуваній суспензії; знехтування необхідністю додавання диспергуючої речовини в розчин, оскільки глинисті часточки мають властивість утворювати мікроагрегати (рис. 2, б); недостатня змочуваність частиночок породи розчинником; необхідно виключити можливість потрапляння до комірки частинок розміром >2 мм шляхом попереднього просіювання зразків що містять крупні частки; забруднене скло комірки, через яку проходить лазерний промінь; недостатня кількість проведених циклів вимірювань.

\section{ВИСНОВКИ}

1. Використання седиментографа дає можливість характеризувати весь спектр розмірностей частинок зразка.

2. Результати значною мірою залежать від мінерального складу і форми частинок досліджуваних зразків. Неточно задані параметри при проведенні вимірювань можуть призвести до похибок.

3. Визначення розміру частинок при використанні даного приладу базується на розрахункових моделях для частинок плоскої сферичної та сферичної форми. У випадку аналізу розподілу частинок неправильної форми застосування цих моделей виникає певні сумніви.

4. Суттєвою перевагою використання даного приладу $€$ швидкість проведення вимірювань, оскільки описані вище класичні методи є досить довготривалими й трудомісткими, вимагають різноманітного обладнання.

5. Використання даного приладу дає можливість водночас працювати з піщаними й глинистими породами, не розподіляючи їх на окремі фракції.

6. Бажаний результат досліджень отримується шляхом врахування факторів, що можуть призвести до виникнення похибки вимірювань. 
7. Необхідно враховувати, що через конструктивні особливості приладу (власне комірки) при аналізі гранулометричного складу, зразків які містять частки розміром $>1$ мм в результатах розподілу частинок цієї фракції можуть виникати незначні похибки.

8. Отримані результати гранулометричного складу дають можливість класифікувати породу або визначати генезис залежно від поставлених перед дослідником завдань.

9. При використанні седиментографа отримуємо результати аналізу гранулометричного складу осадових порід у вигляді розподілу частинок за розміром із значною точністю, проте при цьому не одержуємо розподілу досліджуваного зразка на фракції.

10. Доцільно використовувати даний прилад для детального вивчення попередньо виділених окремих фракцій, оскільки в чітко визначеному діапазоні результати будуть більш точними і надійними.

1. Алексеев Е.В. Совершенствование прибора и метода анализа гранулометрического состава порошков на основе слоевой седиментации частиц. Дис. канд. тех. наук. - Томск, 2006.

2. Ахманов С.А., Никитин С.Ю. Физическая оптика.Москва.: Изд-во МГУ, 1998.

3. Каули Дж. Физика дифракции. - Москва.: Мир, 1979.

4. Лазаренко Є.К. Курс мінералогії. - Київ.: 1970, С. 399-423.

5. Ломтадзе В.Д. Физико-механические свойства горнах пород //Методы лабораторных исследований. Ленинград.: «Недра», 1990.

Institute geological sciences NAS of Ukraine, Kiyv, Ukraine Інститут геологічних наук НАН України, м. Київ, Україна
6. Миловский А.В., Кононов О.В. Мінералогія. - Москва.: Із МГУ, 1982. С. 38.

7. Пустовалов Л.В. Петрография осадочных пород// Осаждение составляющих частиц осадков. - Москва.; Ленинград.: Госнаучтехиздат, 1940. - Ч. І. C. 248-259.

8. Страхов Н. М. Методы изучения осадочных пород.Москва.: 1957.С.314-340, 396-402.

9. Федоров Б. Ф. Лазеры. Основы устройства и применение.- Москва.: ДОСААФ, 1988. 